\title{
Emotional support to the family of the critically ill patient: nursing interventions
}

Apoio emocional à família da pessoa em situação crítica: intervençôes de enfermagem Apoyo emocional a la familia de la persona en situación crítica: intervenciones de enfermería Dulce dos Santos Gaspar Cabete* (D); Cristina Santos da Fonte** (D); Melissa Martins Silva de Matos*** (D); Helena Mendes Patrica**** (D); Ana Rita Ribeiro Silva*****iD; Vânia Filipa Valadão de Abranches Silva****** (iD

\begin{abstract}
Background: It is argued that patients' family should be included into the nursing care plan, not only as a partner but also as a recipient of care. However the severity and emergency of situations in the context of critical care, lead nurses to focus on technological aspects of care somehow disregarding human and family care.

Objective: To identify the emotional needs of critical patients' family as well as nursing interventions responding to those needs.

Methodology: An integrative literature review was performed in Science Direct and EBSCO search engines considering PICo structure (Population, Interest, Context). Six papers matched the search criteria.

Results: Family needs to be given clear and honest information, to set a relationship based on proximity and trust with professional caregivers, to express their feelings and to nourish a realistic trust.

Conclusion: Even if some form of consensus was found between different authors, the limited number of retrieved papers point out the need for further research.
\end{abstract}

Keywords: critical care; family; nursing care; emotions

\section{Resumo}

Enquadramento: Afirma-se constantemente que a família do cliente deve ser integrada no plano de cuidados, não só como parceiro, mas também como alvo de cuidados. Contudo, em contexto de cuidados à pessoa em situação crítica, a gravidade e a emergência das situaçôes clínicas levam a que as intervençôes se centrem na vertente tecnológica, relegando para segundo plano a atenção à família.

Objetivo: Identificar necessidades emocionais sentidas pela família da pessoa em situação crítica e intervençóes de enfermagem que respondam a essas necessidades.

Metodologia: Realizou-se uma revisão integrativa da literatura, através dos motores de busca EBSCO e ScienceDirect, organizando os termos de pesquisa de acordo com a estrutura PICo (Populaçáo, Interesse e Contexto). Obtiveram-se 6 artigos para análise.

Resultados: A família sente necessidade de informação clara e honesta, de estabelecer uma relaçáo de proximidade e confiança e de poder exprimir sentimentos e alimentar uma esperança realista.

Conclusáo: Apesar do consenso encontrado, o reduzido número de artigos aponta para a necessidade de mais investigação nesta temática.

Palavras-chave: cuidados críticos; família; cuidados de enfermagem; emoçôes

*Ph.D., Adjunct Professor, Nursing School of Lisboa, 1600-190, Lisboa, Portugal [dscabete@esel.pt]. (1) https://orcid.org/0000-0003-4859-5827. Contribution to the article: study supervision and writing of the article. Address for correspondence: Avenida Professor Egas Moniz, 1600-190, Lisboa, Portugal.

**Graduate, NR, Hospital Dona Estefânia, 1169-045, Lisboa, Portugal [cristinasdafonte@ gmail.com].(1) https://orcid.org/0000-0002-9223-0561. Contribution to the article: study development.

***Graduate, NR, Hospital Garcia de Orta, 2805-267, Almada, Portugal [melymatos11@ hotmail.com].(1) https://orcid.org/0000-0001-6258-6092. Contribution to the article: study development.

****Graduate, NR [lenapatrica@ hotmail.com].(1) https://orcid.org/0000-0002-14925907. Contribution to the article: study development.

*****Graduate, NR, Hospital Garcia de Orta, 2805-267, Almada, Portugal [arrs96@ hotmail.com].(I) https://orcid.org/0000-0001-9613-5353. Contribution to the article: study development.

******Graduate, NR, Instituto Valenciano de Infertilidade, 1800-218, Lisboa, Portugal [vaniaabranches@gmail.com]. (Dhttps://orcid.org/0000-0002-7990-8569.Contribution to the article: study development.

Revista de Enfermagem Referência

\section{Resumen}

Marco contextual: Se afirma constantemente que la familia del paciente debe ser integrada en el plan de cuidados, no solo como compańera, sino también como objeto de estos cuidados. No obstante, en el contexto de los cuidados, la persona en situación crítica, la gravedad y la urgencia de las situaciones clínicas llevan a que las intervenciones se centren en la vertiente tecnológica, y releguen a un segundo plano la atención a la familia.

Objetivo: Identificar las necesidades emocionales sentidas por la familia de la persona en situación crítica y las intervenciones de enfermería que respondan a esas necesidades. Metodología: Se realizó una revisión integradora de la literatura, a través de los motores de búsqueda EBSCO y ScienceDirect, y se organizaron los términos de la investigación de acuerdo con la estructura PICo (Población, Interés y Contexto). Se obtuvieron 6 artículos para el análisis.

Resultados: La familia siente necesidad de información clara y honesta, de establecer una relación de proximidad y confianza, así como de poder expresar sentimientos y alimentar una esperanza realista.

Conclusión: A pesar del consenso encontrado, el reducido número de artículos apunta a que es necesario realizar más investigaciones sobre esta temática.

Palabras clave: cuidados críticos; familia; atención de enfermería; emociones 


\section{Introduction}

Throughout the vital cycle, the human being experiences challenges and changes which need to be dealt with, mobilizing his/her resources for the maintenance of health and well-being. However, if some changes are desired and occur predictably, acute illness or an accident leading to hospitalization in an intensive care unit constitutes itself as an abrupt transition from a state of health to a critical condition, which requires adaptation mechanisms from the patient and their family (Mendes, 2018). Since the experience of the disease is a process that affects the entire family, it is crucial that the nursing care is not limited to the interaction between the nurse and the patient, because the family should be involved not just as a resource to help the sick person, but also as a care target. However, concerning the critically ill person, the care directed to family members is hardly visible, one would say even little present and poorly structured, as it is not common to find in the patient file references to diagnostics or nursing interventions that target the needs of the family (Knapp, Sole, \& Byers, 2013). This does not mean that nurses ignore the relatives of the critically ill person, but that, given the severity of the disease situation, their needs can become secondary or are even generally unknown.

It is relevant to highlight that, in addition to being an unknown environment, the physical context of the intensive care unit can be frightening for the family due to the number of devices surrounding the person in a critical situation, which becomes itself a stress-generating factor. The intensive care units are "highly specialized services designed to ensure health care to individuals with severe organ dysfunction, which frequently implies a commitment to life" (Carvalhido, 2012, p. 19). This health care is designated by Marshall et al. (2017) as intensive care or critical care and refers to a provision of care performed by a specialized multidisciplinary team to the individual in a life-threatening situation due to organ dysfunction or at risk of developing it. It is also important to emphasize that the family "has the perception that in that context of hospitalizatio ... the physical instability of the inpatients is highly compromised, and many of the situations end in death" (Mendes, 2018, p. 186).
Thus, because of all the present technological and care environment that is generated around the critically ill patient, and because the situation of critical illness occurs many times in an abrupt manner, the family needs to adopt an almost immediate coping mechanism, so it is important to support the family in this struggle (Mendes, 2018). However, meeting the family's needs constitutes a challenge for nurses, who report as their major difficulties not only the management of sincere and honest information on the patient's clinical status, while trying at the same time to maintain hope, but also the lack of confidence to approach the family of the critically ill patient. Conflicts may arise, when nurses create very high expectations regarding the results of care to the family of critically ill patients, as they desire to be able to extinguish or delete all the restlessness, anxiety, and emotional pain of the family, which eventually builds an unrealistic goal (Sá, Botelho, \& Henriques, 2015). Therefore, it is important to recognize, support, and meet the emotional needs of family members of critically ill patients.

Thus, the objective of this study is to identify needs felt by the family of the critically ill person and nursing interventions that meet these needs, while answering to the following research questions: a) What are the emotional needs of the family of the critically ill patient? b) What are the nursing interventions that meet the emotional needs of the family of the critically ill patient?.

For the purposes of this review, the following definition of terms is taken into account: Critically ill person - "the patient whose life is threatened by failure or imminent failure of one or more vital functions and whose survival depends on advanced means of surveillance, monitoring, and therapy" (Ordem dos Enfermeiros, 2011, p. 1), that is, the adult patient hospitalized in an intensive or intermediate care unit; Family - "social unit or collective whole composed of persons related to each other by consanguinity, affinity, emotional or legal relations, considering the unit or the whole as a system that is greater than the sum of its parts" (Ordem dos Enfermeiros, 2011, p. 115), meaning those who identify themselves as such and who visit the hospitalized critically ill person; Emotional Support - response to a non-satisfied 
need that increases the level of anxiety of those involved in the action, that is, of the patient and his/her family (Figueiredo, 2009). This response is achieved through nurses' interventions, whose goal is helping to overcome the moment in which they find themselves, to understand the patient's health problem, and to face it in a healthy way (Phaneuf, 2005); Nursing interventions - any action based on clinical judgment and knowledge, performed by nurses in favor of better results, for a patient and/or family (Bell, 2007). The interventions to the family have a key role of support and education. On the one hand, the psychological support aims to respond to the feelings that the time and the situation arouse in the family through the resolution of internal conflicts and participation in care. On the other hand, education based on communication of information and adaptation to the patient's health problem aims to prepare individuals for the replacement on care, for the reception of unexpected news, or for a better adaptation to the clinical condition of their relative (Phaneuf, 2005).

\section{Methodological procedures of integrative review}

To answer the research question, we have developed an integrative review of the literature, according to the structure of Cronin, Ryan, and Coughlan (2008), which includes four steps: 1) selection of the topic for review - this step, as described previously, culminated with the selection of the theme "emotional support to the family of the critically ill person: nursing interventions"; 2) literature survey - the initial research that allows justifying the relevance of the topic to be studied (already mentioned above) and defining the research terms, whose process is described below; 3) systematized collection of publications, reading, and analysis of literature; 4) description and discussion of the obtained results, elaboration of a table showing the interventions identified in the selected articles and proposals on the basis of these results.

The formulation of a guiding strategy of the well-designed research and the definition of inclusion and exclusion criteria are essential to confer validity and rigor to a literature review. The search of articles for this review was based on the PICo method, including quantitative and qualitative researches (Jose, 2009), which considers $(\mathrm{P})$ the population of interest for the study and its characteristics, (I) the phenomenon of interest and (Co) the context of this phenomenon and population. In this review, the target population $(\mathrm{P})$ are the relatives of the critically ill person, the focus of interest (I) are the emotional needs of family members, and the context $(\mathrm{Co})$ is the inpatient care for critically ill people. The search engines EBSCO and ScienceDirect were used to define descriptors in the English language, as presented in Figure 1 . The database survey was performed on 24 April 2018, by two of the authors at the same time, to make peer to peer validation of the information collection.
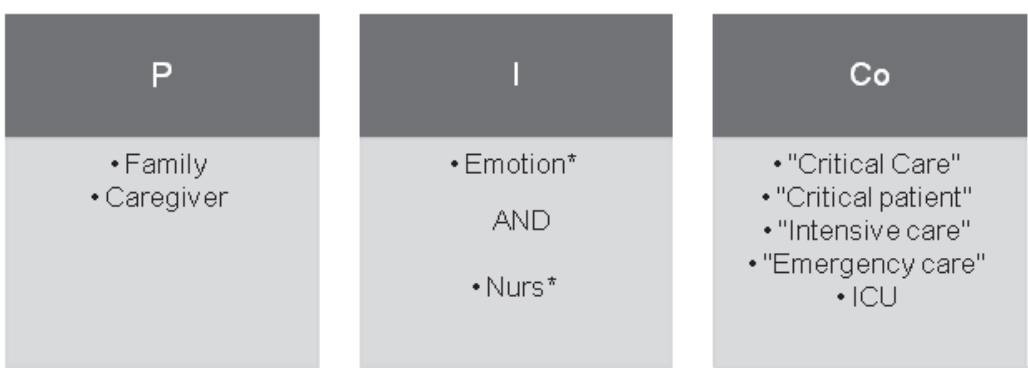

Figure 1. Descriptors used in the database survey. 
The first survey was carried out in the search engine EBSCO, including the following databases: Academic Search Complete; CINAHL Plus with Full Text; Cochrane Central Register of Controlled Trials; Cochrane Database of Systematic Reviews; MedicLatina; MEDLINE with Full Text, and Psychology and Behavioral Sciences Collection. The option of surveying multiple databases simultaneously is because it allows immediately the elimination of duplicates. The search terms were organized as shown in Figure 1: [ (family) OR (caregiver)] AND [emotion*] AND [nurs*] AND [(critical care) OR (critical patient) or (intensive care) OR (emergency care) OR (ICU)]. In a second phase, we repeated the survey through ScienceDirect, using the same search criteria. In a third phase, the survey was completed with the use of bibliographic references suggested in the consulted texts. Filters were applied to the results of the conducted survey: language (being available in
English, Portuguese, or Spanish) and accessibility in full text, which significantly reduced the available material, so we chose not to add a date filter. Following this selection, there was the reading of the articles' titles and later the full articles, with the purpose of checking the inclusion criteria, namely: a) to be directed to the context of the adult/elderly b) to consider as target population the family of critically ill patients c) to be an article of empirical research, regardless of the used methodology. Figure 2 shows the outcome of the application of inclusion and exclusion criteria, which resulted in a total of six articles for analysis, published between 2009 and 2016, using the flowchart provided by the software Prism Flow Diagram Generator. The whole process of application of inclusion and exclusion criteria was verified independently by four authors and an experienced researcher, who provided consensus in the obtained results.

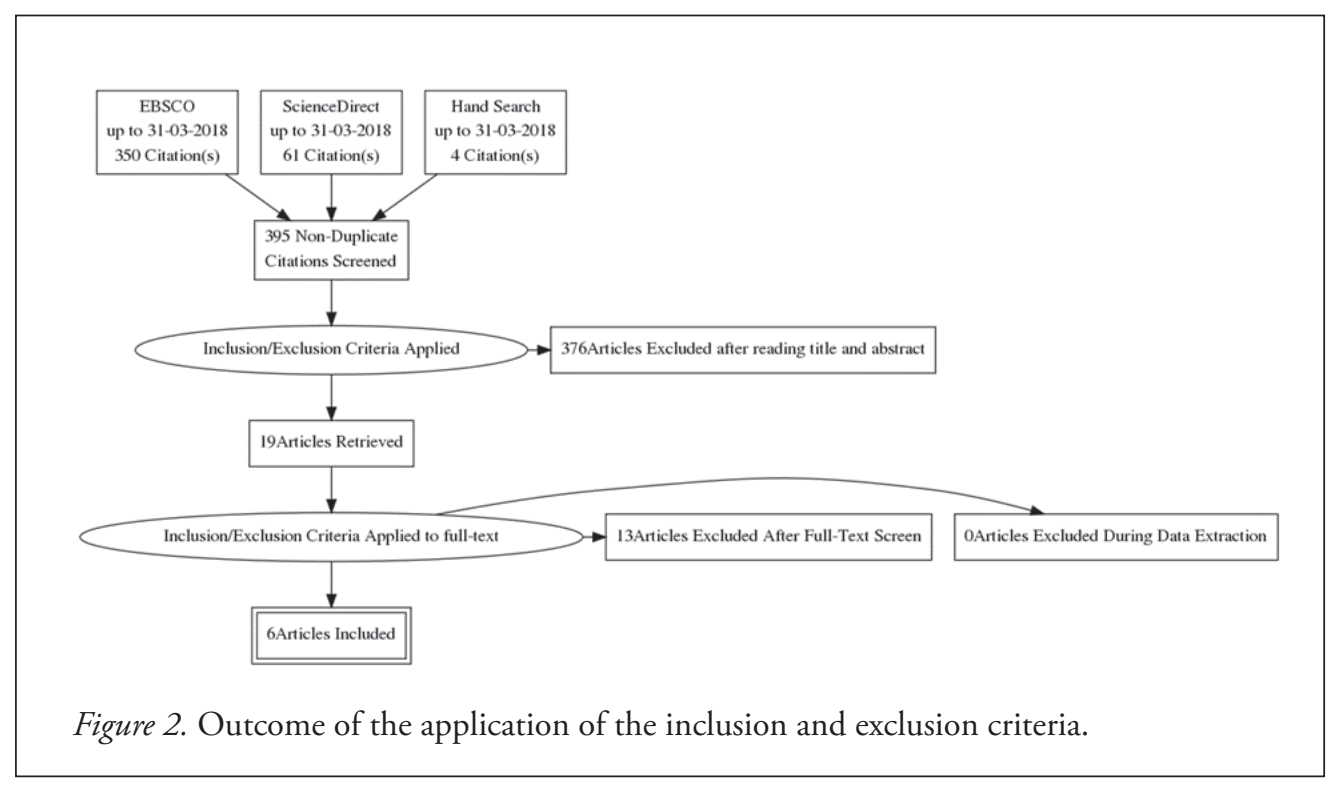

Thirteen articles were eliminated during the phase of full-text reading because they did not meet the inclusion/exclusion criteria, in particular for including the pediatric population, for not being limited to the environment of care to the critically ill person, or because the participants in the study were health professionals and not patients and their families.

\section{Results and interpretation}

To facilitate the analysis of the results, we elaborated a summary table (Table 1 ), in chronological order. 
Table 1

Summary of the analyzed articles

\begin{tabular}{|c|c|c|c|c|}
\hline Article & $\begin{array}{l}\text { Type of } \\
\text { article }\end{array}$ & $\begin{array}{l}\text { Objectives of the } \\
\text { Study }\end{array}$ & $\begin{array}{l}\text { Family's } \\
\text { needs }\end{array}$ & $\begin{array}{l}\text { Nursing } \\
\text { interventions }\end{array}$ \\
\hline $\begin{array}{l}\text { Kinrade, T., Jackson, A. } \\
\text { C., \& Tomnay, J. E. } \\
\text { (2009). The psychosocial } \\
\text { needs of families } \\
\text { during critical illness: } \\
\text { Comparison of nurses' } \\
\text { and family members' } \\
\text { perspectives. Australian } \\
\text { Journal of Advanced } \\
\text { Nursing, 27(1), 82-88. }\end{array}$ & $\begin{array}{l}\text { Exploratory } \\
\text { study of quan- } \\
\text { titative nature, } \\
\text { with application } \\
\text { of an inventory } \\
\text { of evaluation. } \\
\text { Convenience } \\
\text { sample with } 25 \\
\text { family members } \\
\text { and } 33 \text { nurses in } \\
\text { an ICU. }\end{array}$ & $\begin{array}{l}\text { To explore the } \\
\text { psychosocial } \\
\text { needs of family } \\
\text { members, } \\
\text { comparing the } \\
\text { point of view of } \\
\text { the family with } \\
\text { the point of view } \\
\text { of nurses. }\end{array}$ & $\begin{array}{l}\text { To feel that the } \\
\text { professionals are } \\
\text { concerned with the } \\
\text { hospitalized relative; } \\
\text { To receive informa- } \\
\text { tion about the pa- } \\
\text { tient's condition; } \\
\text { To receive realistic } \\
\text { hope. }\end{array}$ & $\begin{array}{l}\text { To inform the } \\
\text { family about the } \\
\text { patient's condition; } \\
\text { To give realistic } \\
\text { hope to family } \\
\text { members. }\end{array}$ \\
\hline $\begin{array}{l}\text { Hashim, F., \& H ussin, R. } \\
\text { (2012). Family Needs } \\
\text { of Patient Admitted to } \\
\text { Intensive Care Unit in a } \\
\text { Public Hospital. Procedia } \\
\text { - Social and Behavioral } \\
\text { Sciences, 36(June 2011), } \\
\text { 103-111. }\end{array}$ & $\begin{array}{l}\text { A qualitative study, } \\
\text { cross-sectional } \\
\text { and descriptive, } \\
\text { by questionnaire } \\
\text { to } 110 \text { relatives } \\
\text { of people hospi- } \\
\text { talized in ICU, } \\
\text { in a random } \\
\text { sample. }\end{array}$ & $\begin{array}{l}\text { To identify and } \\
\text { prioritize needs } \\
\text { of the family of } \\
\text { the admitted to } \\
\text { the intensive care } \\
\text { unit. }\end{array}$ & $\begin{array}{l}\text { To receive honest } \\
\text { information about } \\
\text { the condition and } \\
\text { prognosis of the } \\
\text { patient; } \\
\text { To witness concern } \\
\text { with the patient; } \\
\text { To have hope and be } \\
\text { comforted; } \\
\text { To feel support, } \\
\text { closeness and, safety } \\
\text { from professionals. }\end{array}$ & $\begin{array}{l}\text { To contact the } \\
\text { family whenever } \\
\text { there are changes in } \\
\text { the state of health } \\
\text { of the patient; } \\
\text { To honestly answer } \\
\text { the questions of } \\
\text { family members; } \\
\text { To extend/adapt } \\
\text { visiting hours. }\end{array}$ \\
\hline
\end{tabular}

Gaeeni, M., Farahani, M.

A., Seyedfatemi, N.,

\& Mohammadi, N.

(2015). Informational

Support to Family

Members of Intensive

Care Unit Patients: The

Perspectives of Families

and Nurses. Global

Journal of Health

Science, 7(2), 8-19.
A qualitative and descriptive study, per semi-structured interviews to 19 family members and 12 nurses

- convenience sample in an ICU.
To explain the perspectives of family members and nurses about informational support.

To support physically and mentally the family members;

To obtain information; To show empathy To receive the sup- with the families port of professionals; and their situation; To express emotions To adapt and faciliand feelings. tate the use of coping strategies used by family members; To provide real, complete, and honest information.

Quantitative,

Pelazza, B. B., Simoni, R. C. M., Freitas, E. G. B., Silva, B. R. da, \& Silva, M. J. P. da (2015). Visita de Enfermagem e dúvidas manifestadas pela família em unidade de terapia intensiva. ACTA Paulista de Enfermagem, 20, 60-65. cross-sectional, and prospective study. Participants: 115 family members of patients hospitalized for more than 24 hours.

Convenience sample.
To know the doubts of the family members of patients hospitalized for more than 24 hours in the intensive care unit.

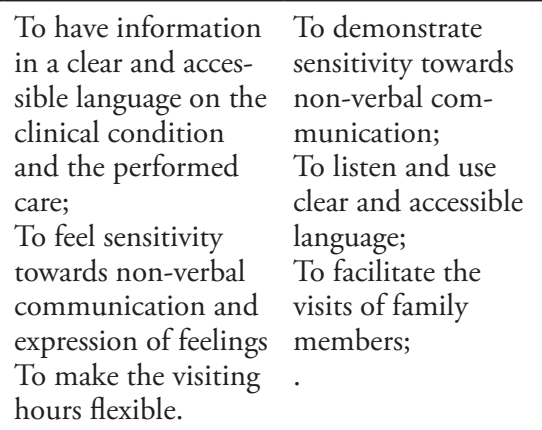


Bandari, R., Heravi-

Karimooi, M., Rejeh, N., Quantitative, Mirmoham madkhani, cross-sectional, M., Vaismoradi, M., \& Snelgrove, S. (2015). Information and support needs of adult family members of patients in intensive care units: an Iranian perspective. Journal

of Research in

Nursing, 20(5), 401-422. and descriptive study, conducted by the survey to 450 family members of critically ill patients; random sample in 27 public hospitals.
To describe the needs of family members of patients hospitalized in an intensive care unit in an Iranian urban area.
To have their doubts clarified with honesty;

To be assured that their family member is receiving the best possible care; To feel that there is hope; To receive perceptible explanations; To learn specific facts regarding the progress of their relative.
Rodríguez, L. M. B., Velandia, M. F. A., \& Leiva, Z. O. C. (2016). Percepcíon de los familiares de los pacientes críticos hospitalizados com respecto a la comunicacíon y apyo emocional. Revista CUIDARTE, 7(2), 1297 1309
Quantitative, cross-sectional, descriptive study, with a sample of 200 family members selected by convenience sample.
To assess the perception of family members of critically ill patients regarding verbal and non-verbal communication and emotional support offered by nurses during hospitalization.
Clear, credible, and family-adapted communication;

To receive information in a calm and comfortable environment;

To receive emotional support;

To promote comfort and well-being; Demonstration of empathy through communication, affection, and tact.
To communicate in a clear and credible manner that is adapted to the socio-cultural level of the family; To communicate with a calm voice, and appropriate posture and facial expression; To convey information in a calm and comfortable environment; To support emotionally; To promote comfort and well-being; To demonstrate empathy through communication, affection, and tact.
After the full-text reading and analysis of the articles identified above, we proceeded to the analysis of the results and their respective conclusions, to systematize the answers to these questions: What are the emotional needs of the family of the critically ill patient? Which nursing interventions were identified?

\section{Emotional needs of the family}

The family of the hospitalized patient experiences feelings of uncertainty, fear, anxiety, and helplessness, related to their clinical situation and the lack of information, which sometimes lead to feelings of depression and guilt. There is also the fear of questioning the health professional team and the struggle in perceiving the information supplied by them (Gaeeni, Farahani, Seyedfatemi, \&
Mohammadi, 2015). The identified needs are associated with receiving adequate clinical information from the present health professionals because family members are afraid of questioning or bothering them. Moreover, they feel the need to relive the critical incident that resulted in the hospitalization of the patient, as well as to be encouraged to express their feelings. Concerning the need to receive information, Pelazza, Simoni, Freitas, Silva, and Silva (2015) refer that family members feel the need to understand the diagnosis and prognosis of the hospitalized relative, as well as to know the care strategies. This information should be updated and clear. Gaeeni et al. (2015) and Hashim and Hussin (2012) add that health professionals should offer support to families, showing concern for the critically ill patient and providing realistic hope. 
In 2015, Bandari et al., conducted an inventory, using Molter's instrument, which corroborates the previously identified needs and differentiates needs perceived as more important - such as feeding hope, feeling safety in care and having honest and appropriate information - from others that exist but are less important for the family, such as having religious support, being encouraged to cry, having time and space to stay alone in the hospital, but being accompanied during their visit in the intensive care unit, having the opportunity to speak about the death of their relative, being informed of the existence of entities that collaborate in the resolution of family problems, and having someone to help with the financial problems.

In summary, we could say that the emotional needs of family members, identified in this review, are included in three dimensions: $\operatorname{cog}$ nitive, emotional, and relational. Need for updated, clear, and honest information, related to the clinical status of the hospitalized patient, prognosis, and strategies of care; Need for emotional support related to the expression of feelings and to receive hope in a realistic manner; Need to establish a relationship of closeness and security, in which they can see manifestation of concern for the critically ill patient.

\section{Nursing interventions}

The nursing interventions that meet the needs of family members of the critically ill person, identified in this review, are not surprising and reinforce the need to not forget some aspects of clinical practice, namely in the relational field, in an environment where the urgency and complexity of care justify so often the prioritization of their technological dimension.

Pelazza et al. (2015) and Rodríguez, Velandia, and Leiva (2016) stress the importance of establishing an empathetic relationship with the family, promoting hope and communicating in a clear and accessible manner, also adapted to their sociocultural level, thus emphasizing the promotion of a private and comfortable environment during the visit, focusing on their well-being. The use of resources is essential to include family members in the process of care provision, guiding them and referencing them where appropriate to other health care professionals. It is equally important to provide real, complete, and honest information, by contacting the family whenever the patient's condition changes (Kinrade, Jackson, \& Tomnay, 2009; Hashim \& Hussin, 2012; Gaeeni et al., 2015; Bandari et al., 2015; Rodríguez et al., 2016). In fact, the response to the patient's and his/ her family's right to have up-to-date, clear, and honest information, related to the clinical condition, prognosis, and care strategies, is part of the information obligation provided for in Article 84 of the Ethics Code of Nurses (Ordem dos Enfermeiros, 2009).

The manifestation of empathy, respect, and sensitivity, as well as emotional and spiritual support to the family, are presented as major interventions, which meet the needs of family members (Gaeeni et al., 2015; Pelazza et al., 2015). Hashim and Hussin (2012), Gaeeni et al. (2015), and Bandari et al. (2015) acknowledge the emotional support through the promotion of expression of feelings and the realistic feeding of hope. Hashim and Hussin (2012) and Kinrade et al. (2009) emphasize the closeness, security, and manifestation of concern for the critically ill patient as needs perceived by the family.

Caring for the critically ill person and his/ her family requires that health professionals, especially nurses, develop behavioral and relational skills that adequately meet the identified needs. However, although the importance of nurses is highly acknowledged in the aid and response to families of critically ill patients, they do it often as a spontaneous and intuitive action, rather than planned or deliberate (Knapp et al., 2013).

An aspect to consider in response to the family's needs is that their presence in the care unit occurs in a tight schedule, often interrupted by the sudden change in the clinical status of the patient and by the admission of others, which may generate discomfort and insecurity. Therefore, it is crucial to inform the family about the environment that surrounds the critically ill person and optimize it, because the knowledge of the environment promotes positive coping (Gonçalves, 2015). So, the flexibilization of the visiting hours is described as an intervention that promotes the relationship between the family and the nursing team and the critically ill person (Pelazza 
et al., 2015; Hashim \& Hussin, 2012).

Family members feel the need to be informed about the status of the patient and the care being provided in a language they understand, but there are some fear and difficulty in questioning and/or using the right questions that allow them to get answers to their questions and needs (Zaforteza, Sánchez, \& Lastra, 2008). Thus, the need for information can be masked by this difficulty, meaning that nurses must have initiative.

Consequently, it is important that nurses talk to the family, allow them to manifest their doubts and fears, and answer them safely, clearly, and truly. If the initiative to inform comes from the healthcare professional, the family feels more confident and understood, being able to express their feelings and difficulties. If the themes of the hospitalization causes, of the description of the environment and the provided care, and the patient's reaction are addressed, the family perceives what was and is being done and how they can be useful in care provision. In addition, the environment of a critically ill person care unit, as well as the complexity of clinical situations, can be disfavoring factors for the establishment of a relationship with the family, given that their needs are not urgent or emerging. However, the visible and permanent physical presence of the nurse with the client and in-depth knowledge of his/her condition is supporting factors so that during those visiting moments nurses have the ideal opportunity to respond to the family's needs (Bijttebier, Vanoost, Delva, Ferdinande, \& Frans, 2001). This relationship is only possible when the nurses identify the needs of the family and respond to them effectively, through the initiative, clarity, protection of their interests, and clarification of care.

In a nutshell, the interventions found in this review include: To establish a relationship with the family, promoting hope, communicating in a manner that is not only clear and accessible but also adapted to their sociocultural level; To promote a private and comfortable environment during the visit, ensuring the well-being of the family; To use the resources to include the relatives in care, guiding them throughout the process and referencing them, where appropriate, to other health care professionals; To provide real, complete, and honest information, by contacting the family whenever there are changes in the patient's clinical situation; To manifest empathy, respect, and sensitivity, as well as to provide spiritual and emotional support to the family; To adjust visiting hours.

\section{Conclusion}

The research allowed identifying needs and nursing interventions directed to the family of the critically ill person, in this case, from the point of view of the patient. The need for updated and honest information, for expression of feelings with the transmission of realistic hope, for closeness and security, and for concern manifested by health professionals are the key aspects. To fulfill these needs, it is crucial for the nurse to establish a relationship with the family, to promote a comfortable and private environment, to provide real and complete information, and to demonstrate empathy, respect, and sensitivity while including the family in care provision. The results and discussion of this study have implications in clinical practice, in care management, professional training, and research. Firstly, it is important that the nurses become aware of the needs of family members and establish a relationship with them in an intentional and structured manner, including this attention in the planning of care. As regards care management, an aspect that stood out in this review was the need for the flexibilization of family presence hours.

Finally, it is also relevant to the authors that this research is expanded, given that some limitations were identified after its conclusion. On the one hand, the decision to conduct the research simultaneously in multiple databases can lead to a lower specificity of the search terms. On the other hand, the decision to include only articles available in full text in the databases meant that some information different from that which was found could eventually add value and rigor to this work. To remedy this deficit, some authors were contacted, which revealed to be not an effective strategy within the time available for the conduction of the research.

However, despite the limitations, the conclusions are considered valid in relation to the 
articles found, and the shortage of the research found in answer to the research question underlines the importance of promoting the conduction of research on this theme, giving voice to the patient and his/her family in the process of care.

\section{References}

Bandari, R., Heravi-Karimooi, M., Rejeh, N., Mirmohammadkhani, M., Vaismoradi, M., \& Snelgrove, S. (2015). Information and support needs of adult family members of patients in intensive care units : An Iranian perspective. Journal of Research in Nursing, 20(5), 401-422. doi: 10.1177/1744987115591868

Bell, J. M. (2007). Research on family interventions. In Families and health: A systemic approach in nursing care (2nd ed., pp. 1-34). Montreal, Canada: .

Bijttebier, P., Vanoost, S., Delva, D., Ferdinande, P., \& Frans, E. (2001). Needs of relatives of critical care patients: Perceptions of relatives, physicians and nurses. Intensive Care Medicine, 27(1), 160-165. doi: 10.1007/s001340000750

Carvalhido, J. P. (2012). Práticas relacionais dos enfermeiros com a familia em unidades de cuidados intensivos (Master's Thesis). Retrieved from https:// repositorio-aberto.up.pt/handle/10216/77880

Cronin, P., Ryan, F., \& Coughlan, M. (2008). Undertaking a literature review: A step-by-step approach. British Journal of Nursing, 17(1), 38-43. doi: 10.12968/bjon.2008.17.1.28059

Figueiredo, M. H. (2009). Enfermagem de familia: Um contexto do cuidar (Ph.D. Thesis). Retrieved from https://repositorio-aberto.up.pt/handle/10216/20569

Gaeeni, M., Farahani, M. A., Seyedfatemi, N., \& Mohammadi, N. (2015). Informational support to family members of intensive care unit patients: The perspectives of families and nurses. Global Journal of Health Science, 7(2), 8-19. doi: 10.5539/gjhs.v7n2p8

Gonçalves, J. P. (2015). Cuidar da pessoas doente em situação crítica que vivencia uma situação de stress: Estratégia facilitadora nos processos de transição (Traineeship Report). Retrieved from http://hdl.handle. net/10400.14/20014

Hashim, F., \& Hussin, R. (2012). Family needs of patient admitted to intensive care unit in a public hospital. Procedia - Social and Behavioral Sciences, 36, 103-111. doi: 10.1016/j.sbspro.2012.03.012

Jose, M. (2009). Finding qualitative research: PICo and more. Curtin University. Perth.

Kinrade, T., Jackson, A. C., \& Tomnay, J. E. (2009). The psychosocial needs of families during critical illness: Comparison of nurses' and family members' perspectives. Australian Journal of Advanced Nursing, 27(1), 82-88. Retrieved from http://www.ajan. com.au/vol27/tomnay.pdf

Knapp, S. J., Sole, M. L., \& Byers, J. F. (2013). The EPICS Family Bundle and its effects on stress and coping of families of critically ill trauma patients. Applied Nursing Research, 26(2), 51-57. doi: 10.1016/j.apnr.2012.11.002

Marshall, J. C., Bosco, L., Adhikari, N. K., Connolly, B., Diaz, J. V., Dorman, T., . . . Zimmerman, J. (2017). What is an intensive care unit?: A report of the task force of the World Federation of Societies of Intensive and Critical Care Medicine. Journal of Critical Care, 37, 270-276. doi: 10.1016/j. jcrc.2016.07.015

Mendes, A. P. (2018). Impacto da notícia de doença-crítica na vivência da família: Estudo fenomenológico hermenêutico. Revista Brasileira de Enfermagem, 71(1), 182-189. doi: 10.1590/0034-7167-2016-0163

Ordem dos Enfermeiros. (2011). Regulamento dos Padröes de Qualidade dos Cuidados Especializados em Enfermagem Pessoa em Situação Critica. Retrieved from https://www.ordemenfermeiros.pt/arquivo/colegios/ Documents/PQCEEPessoaSituacaoCritica.pdf

Pelazza, B. B., Simoni, R. C., Freitas, E. G., Silva, B. R., \& Silva, M. J. (2015). Visita de enfermagem e dúvidas manifestadas pela família em unidade de terapia intensiva. ACTA Paulista de Enfermagem, 28(1), 60-65. doi: 10.1590/1982-0194201500011

Phaneuf, M. (2005). Comunicação, entrevista, relação de ajuda e validação. Loures, Portugal: Lusociência.

Rodríguez, L. M., Velandia, M. F., \& Leiva, Z. O. (2016). Percepcíon de los familiares de los pacientes críticos hospitalizados respecto a la comunicacíon y apoyo emocional. Revista Cuidarte, 7(2), 12971309. doi: 10.15649/cuidarte.v7i2.330

Sá, F. L., Botelho, M. A., \& Henriques, M. A. (2015). Cuidar da família da pessoa em situação crítica : A experiência do enfermeiro. Pensar Enfermagem, 19(1), 31-46. Retrieved from http://pensarenfermagem.esel.pt/files/PE_19_1sem2015_31_46.pdf

Zaforteza, C., Sánchez, C., \& Lastra, P. (2008). Análisis de la literatura sobre los familiares del paciente crítico: Es necesario desarrollar investigación en cuidados efectivos. Enfermeria Intensiva, 19(2), 61-70. doi: 10.1016/S1130-2399(08)72746-9 
